\title{
Spontaneous intracardiac contrast in a case with intestinal pneumatosis
}

\author{
Martin Leth-Olsen (ㄷ) ${ }^{1,2}$ Øystein Drivenes, ${ }^{3}$ Wendy Williams, ${ }^{1}$ Siri Ann Nyrnes ${ }^{1,2}$
}

${ }^{1}$ Children's Clinic, St Olavs Hospital University Hospital in Trondheim, Trondheim, Norway ${ }^{2}$ Department of Circulation and Medical Imaging, Faculty of Medicine and Health Sciences, NTNU-Norwegian University of Science and Technology, Trondheim, Norway ${ }^{3}$ Department of Paediatric Surgery, St Olavs Hospital University Hospital in Trondheim, Trondheim, Norway

\section{Correspondence to}

Dr Martin Leth-Olsen; martin.leth-olsen@ntnu.no

Accepted 5 September 2021

\section{DESCRIPTION}

A 4-year-old girl, treated with immunosuppressive medication due to relapse of haemophagocytic lymphohistiocytosis, developed gastroenteritis with norovirus. She showed clinical improvement initially, but her symptoms and shedding of norovirus RNA persisted for many weeks. On day 19, she had increasing reports of stomach cramps, an episode of vomiting and episodes of blood in her stool. On examination, she had persisting tachycardia (heart rate $140 \mathrm{bpm}$ ), her blood pressure fell $(80 / 45 \mathrm{~mm} \mathrm{Hg})$, but central capillary refill time remained normal. Her stomach was painful on deep palpation, but soft and with normal bowel sounds. Laboratory findings revealed a slight increase in c-reactive protein $(11 \mathrm{mg} / \mathrm{L})$, a drop in sodium $(128 \mathrm{mmol} / \mathrm{L})$ and persistent pancytopenia (haemoglobin $93 \mathrm{~g} / \mathrm{L}$, white cell count $0.9 \times 10^{9} / \mathrm{L}$, neutrophil granulocytes $0.73 \times 10^{9} / \mathrm{L}$, thrombocytes $\left.19 \times 10^{9} / \mathrm{L}\right)$.

Due to the drop in blood pressure and in order to guide fluid managements, an echocardiogram was performed (video 1).

The echocardiogram revealed massive amounts of air bubbles in the right atrium and right ventricle, and, furthermore, a noticeable amount of air bubbles in the left heart. Gaseous embolisation from the intestines was suspected. The following abdominal $\mathrm{X}$-ray revealed pneumatosis and possible intrahepatic air. The patient's symptoms progressed rapidly with respiratory and circulatory deterioration. She was therefore rushed to the operating theatre where laparotomy confirmed pneumatosis in the entire colon and distal ileum (figure 1). Surgical colectomy and ileostomy to remove the source of air embolisation were performed. Histology showed pseudomembranous colitis-like changes with large

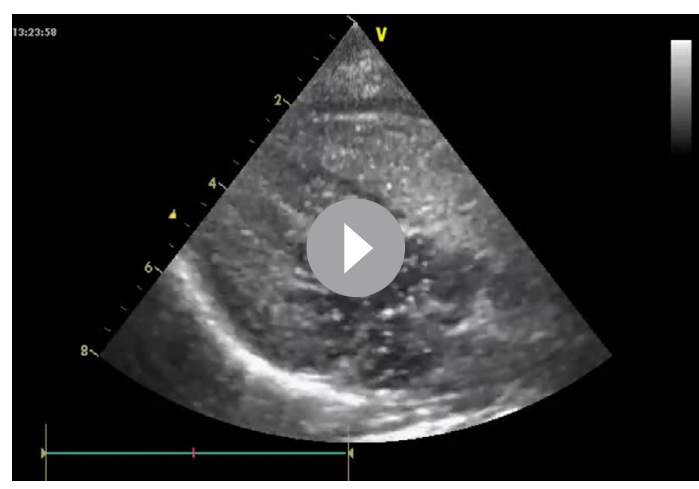

Video 1 Echocardiogram-parasternal long axis reveals massive amounts of air bubbles in the right ventricle and air bubbles in the left heart.
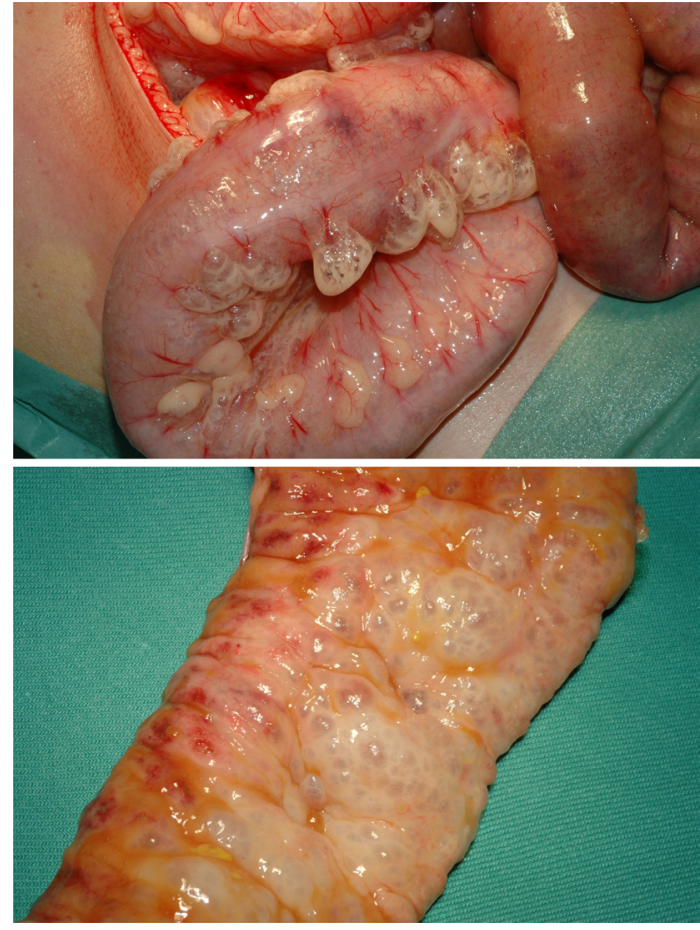

Figure 1 Pneumatosis of the colon.

amounts of air in the mucosa and submucosa. A second look laparotomy 1 day after the colectomy showed viable and well-perfused remaining intestines. A period of challenging intensive care was followed. She had large amounts of hypersecretion from remaining intestine and fluid loss consistent with short bowel syndrome. Three months after the embolisation, a successful allogenic stem cell transplantation was performed. The patient survived and is doing well today.

Gaseous embolisation from the intestines is rare. ${ }^{1}$ This case demonstrates that echocardiography is an ideal imaging modality for rapid assessment of the circulation in critically ill patients. ${ }^{23}$ In this case, echocardiography guided the clinician to the right diagnosis.

\section{Learning points}

Echocardiography is an essential diagnostic tool in the critically ill patient's assessment.

- Gaseous embolisation from intestines is rare but severe and requires immediate attention.

- Immunocompromised patients with norovirusgastroenteritis can experience a prolonged and more severe illness. 
Acknowledgements We are most thankful for the contributions from all involved clinicians at The Childrens clinic at St Olavs hospital.

Contributors All authors have each made a substantial contribution and qualify for authorship. The final version of the manuscript has been evaluated by all authors. $\varnothing D, W W$ and SAN were involved in patient care. Conception and design: SAN and $\mathrm{ML}-\mathrm{O}$. Acquisition of data: the data material includes the patients' medical journal as well as medical images. SAN and ML-O provided access to the data material. $\mathrm{ML}-0$ has communicated with the patient's parents to get consent. Analysis and interpretation of data material: SAN and ML-0. Drafting the manuscript: ML-O. Revising the manuscript: SAN, $\varnothing \mathrm{D}, W \mathrm{~W}$ and $\mathrm{ML}-0$ have all been involved in revising the manuscripts for important intellectual content. All authors have contributed to the manuscript in a substantial way. Final approval of the version published: SAN, $\varnothing \mathrm{D}, \mathrm{WW}$ and $\mathrm{ML}-\mathrm{O}$ have all approved the final version of the manuscript.

Funding The authors have not declared a specific grant for this research from any funding agency in the public, commercial or not-for-profit sectors.
Competing interests None declared.

Patient consent for publication Consent obtained from parent(s)/guardian(s).

Provenance and peer review Not commissioned; externally peer reviewed.

\section{ORCID iD}

Martin Leth-Olsen http://orcid.org/0000-0002-9983-1159

\section{REFERENCES}

1 Abraham BP, Sachdeva R, Vyas PG, et al. An unusual presentation of necrotizing enterocolitis on an echocardiogram. Pediatr Cardiol 2012;33:1427-9.

2 Kutty S, Attebery JE, Yeager EM, et al. Transthoracic echocardiography in pediatric intensive care: impact on medical and surgical management. Pediatr Crit Care Med 2014;15:329-35.

3 Singh Y. Echocardiographic evaluation of hemodynamics in neonates and children. Front Pediatr 2017;5:201.

Copyright 2021 BMJ Publishing Group. All rights reserved. For permission to reuse any of this content visit

https://www.bmj.com/company/products-services/rights-and-licensing/permissions/

BMJ Case Report Fellows may re-use this article for personal use and teaching without any further permission.

Become a Fellow of BMJ Case Reports today and you can:

- Submit as many cases as you like

- Enjoy fast sympathetic peer review and rapid publication of accepted articles

- Access all the published articles

Re-use any of the published material for personal use and teaching without further permission

Customer Service

If you have any further queries about your subscription, please contact our customer services team on +44 (0) 2071111105 or via email at support@bmj.com.

Visit casereports.bmj.com for more articles like this and to become a Fellow 